\title{
Trends of Emergency Calls During the Coronavirus Disease-19 Pandemic in Nur-Sultan
}

\author{
Akerke Chayakova*(i), Marzhan Dauletyarova ${ }^{1}$ D, Daulet Aldyngurov ${ }^{1}$ (D), Aiman Mussina ${ }^{1}$, Roza Suleimenova ${ }^{1}$, \\ Aigul Utegenova ${ }^{1} \mathbb{D}$, Murat Orazbayev ${ }^{2}$, Gulnara Tuyakova ${ }^{2}$ \\ ${ }^{1}$ Department of Scientific-research Activity, NpJSC "Astana Medical University", Astana, Kazakhstan; ${ }^{2}$ Department of Quality \\ Control of Medical Services, "City Ambulance Station”, Nur-Sultan, Kazakhstan
}

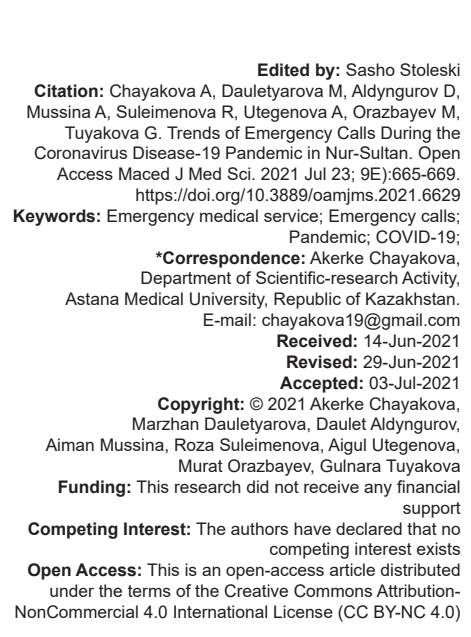

\section{Introduction}

The new coronavirus infection (coronavirus disease [COVID]-19) has become a significant obstacle to life quality and increase of its duration in Kazakhstan, as well as throughout the world. In December 2019, an outbreak of a new coronavirus infection (COVID-19) caused by the severe acute respiratory syndrome coronavirus 2 virus has been reported in Wuhan, China. As of August 1, 2020, the disease has spread widely worldwide with 17,357,662 reported cases. In Kazakhstan, the first cases of COVID-19 were registered on March 13, 2020, and as of August 1, 90,367 cases were registered. The detection and spread of an emerging respiratory pathogen are accompanied by uncertainty about its key epidemiological, clinical, and virological characteristics and, in particular, its ability to spread among the population and virulence (the ratio of the number of cases and severity) [1].

The effect of emergency medical service (EMS) on lowering mortality and morbidity from accidents and socially significant diseases increases its significance worldwide. EMS utilization rates of societies vary relying on local, sociofinancial, and cultural conditions [2], [3], [4]. This study carried out in Nur-Sultan (capital of Kazakhstan) to evaluate the extent of EMS use at some stage in the COVID-19 pandemic. The purpose of the study is to analyze the dynamics of changes in the number of emergency medical calls during outbreak COVID-19, depending on the time of year, day of the week, and the causes for the calls. 


\section{Materials and Methods}

This study retrospectively evaluated the Nur-Sultan (capital of Kazakhstan) EMS data for the period after the pandemic was first registered in Kazakhstan. The necessary permissions for the study were obtained from the Nur-Sultan City Public Health Department. EMS data for the same time interval (February 1-May 1) in the past 3 years $(2018,2019$, and 2020) were compared. All information have been analyzed with the use of SPSS model 23.0. Descriptive statistics used to examine information (frequency, percentage, mean, and standard deviation). Independent samples t-test became used for assessment among groups. $p<0.05$ was considered statistically significant. The data were taken from the database of the automated control system "Komek 103," which is used in the ambulance station since the end of 2019, and the automated information systems "ADIS" used by the ambulance station in Nur-Sultan. We compared the data of emergency medical calls for the same time interval (February 1-May 1) for the past 3 years $(2018,2019$, and 2020). We reviewed the EMS retrospective data concerning prehospital transportation of emergency instances through way of means of emergency medical personnel. An emergency call is described as any incident that calls for emergency help and includes sending an ambulance, irrespective of whether or not the patient turned into taken through way of means of the ambulance to the closest hospital. The database of the automatic system is constructed on the basis of records obtained from the dispatcher both through way of means of phone or through a cellular application. Based on the collected data, cases were divided into four main groups: Medical, traumatic, time-sensitive diseases, and others. The COVID-19-related symptoms category has been added to represent cases with suspected infectious diseases, including, but not limited to, COVID-19 cases.

\section{Results}

The survey interval was February 1-May 1, 2018,2019 , and 2020 years. This report evaluated the EMS data of Nur-Sultan city for this study timespan. While EMS Nur-Sultan acquired 145,009 calls between February 1 and May 1, 2018, for the duration of the identical length, it acquired 148,583 calls in 2019 and 145,510 calls in 2020 . For the term from February 1 to May 1 , the number of calls increased by $2.5 \%$ from 2018 to 2019 and from 2019 to 2020 decreased by $2 \%$. For the period from February 1 to May 1, quantity of instances became 144,964 in 2018 , as compared
Table 1: Statistics of calls

\begin{tabular}{|c|c|c|c|c|c|c|}
\hline \multicolumn{2}{|l|}{ Item } & 2018 & 2019 & $\begin{array}{l}2018-2019 \\
\text { difference }(\%)\end{array}$ & 2020 & $\begin{array}{l}2019-2020 \\
\text { difference (\%) }\end{array}$ \\
\hline \multicolumn{7}{|l|}{ Number of calls } \\
\hline \multicolumn{2}{|l|}{ Total } & 145,009 & 148,583 & 2.46 & 145,510 & -2.07 \\
\hline & & 1629 & 1669 & 2.46 & 1616 & -3.18 \\
\hline \multicolumn{7}{|c|}{ Number of tasks } \\
\hline \multicolumn{2}{|c|}{ Total } & 144,964 & 148,548 & 2.47 & 143,164 & -3.62 \\
\hline \multirow{2}{*}{\multicolumn{7}{|c|}{$\begin{array}{l}\text { Daily } \\
\text { Arrival at scene time (min/s) }\end{array}$}} \\
\hline & & & & & & \\
\hline Mean & & 10:31 & $12: 13$ & 01:42 & 11:10 & 01:03 \\
\hline \multicolumn{7}{|c|}{ Day of the week } \\
\hline Monday & Mean & 21,441 & 22,599 & 0.05 & 21,989 & -0.03 \\
\hline Tuesday & Mean & 20,519 & 21,208 & 3.36 & 20,073 & -5.35 \\
\hline Wednesday & Mean & 18,927 & 20,905 & 10.45 & 21,218 & 1.50 \\
\hline Thursday & Mean & 20,391 & 18,957 & -7.03 & 21,564 & 13.75 \\
\hline Friday & Mean & 20,449 & 20,751 & 1.48 & 21,494 & 3.58 \\
\hline Saturday & Mean & 21,091 & 21,439 & 1.65 & 19,435 & -9.35 \\
\hline Sunday & Mean & 22,191 & 22,723 & 0.02 & 19,737 & -0.13 \\
\hline
\end{tabular}

to 148,548 in 2019 and 143,164 in 2020 . In this survey interval, the number of instances multiplied by $2.5 \%$ from 2018 to 2019 and reduced by $3.6 \%$ from 2019 to 2020 . For the identical time interval, the arrival time at the scene was $10.31 \mathrm{~min}$ in 2018 , whilst in 2019 , it was $12.13 \mathrm{~min}$, and in 2020 , it was $11.10 \mathrm{~min}$ (Table 1).

Cases of EMS were most frequent on Sundays 22,191 cases in 2018, 22,723 in 2019 and Mondays 21,441 cases in $2018,22,599$ in 2019 , respectively, throughout the pre-pandemic period, whereas during the 2020 pandemic, it occurred on Mondays 21,989 cases and Thursdays 21,564 cases and there was a tendency to reduce the number of calls from the beginning of the day of the week to the weekend (Figure 1).

For the period from February 1 to May 1, the number of male patients was $57,955(40 \%)$ in 2018 , $59,447(40 \%)$ in 2019 , and $67,797(47 \%)$ in 2020 . As statistics shows, the number of male patients increased during the pandemic period, compared to the pre-pandemic period, and showed a difference of $14.05 \%$ increase. For the period from February 1 to May 1, the number of female patients showed $60 \%$ in 2018 and in 2019, respectively, and in 2020 $-53 \%$. During the pandemic, the number of women receiving emergency medical care decreased by $15.41 \%$ compared to the pre-pandemic period. There was a significant difference between the sexes $(p<$ 0.05 ). In the pre-pandemic period (February 1-May 1,2018 ), the average age was $25 \pm 23.8$ years for men and $32.9 \pm 23.6$ years for women. In the period (February 1-May 1, 2019), the average age was 25 \pm 23 years for men and $32.7 \pm 23.6$ years for women. During the pandemic period (February 1-May 1, 2020), the average age was $32.3 \pm 23.7$ years for men and $35.9 \pm 23$ years for women. During the pandemic period, the average age of men and women increased (Table 2).

During the pandemic period (February 1May 1,2020), the number of patients in the age group of $0-6$ years remained at a relatively similar level as in the per-pandemic period $(0.9 \%)$. In the age group of $7-18$ years $(-8.4 \%)$, there was a 
Table 2: Comparison of cases by years

\begin{tabular}{|c|c|c|c|c|c|c|}
\hline Item & $\begin{array}{l}2018(n= \\
144,964)\end{array}$ & $\begin{array}{l}2019(\mathrm{n}= \\
148,548)\end{array}$ & $\begin{array}{l}\text { Annual } \\
\text { difference \% }\end{array}$ & $\begin{array}{l}2020(n= \\
143,164)\end{array}$ & $\begin{array}{l}\text { Annual } \\
\text { difference \% }\end{array}$ & p-value \\
\hline \multicolumn{7}{|l|}{ Gender } \\
\hline Male & $\begin{array}{l}57,955 \\
(40 \%)\end{array}$ & $\begin{array}{l}59,447 \\
(40 \%)\end{array}$ & $2.57 \%$ & $\begin{array}{l}67,797 \\
(47 \%)\end{array}$ & $14.05 \%$ & $<0.05$ \\
\hline Female & $\begin{array}{l}87,009 \\
(60 \%)\end{array}$ & $\begin{array}{l}89,101 \\
(60 \%)\end{array}$ & $2.40 \%$ & $\begin{array}{l}75,367 \\
(53 \%)\end{array}$ & $-15.41 \%$ & $<0.05$ \\
\hline \multicolumn{7}{|l|}{ Age (years) } \\
\hline \multicolumn{7}{|l|}{ Mean \pm SD } \\
\hline All & $30 \pm 23.8$ & $29.7 \pm 23.3$ & & $34.3 \pm 23$ & & $<0.05$ \\
\hline Male & $25.3 \pm 23.6$ & $25 \pm 23$ & & $32.3 \pm 23.7$ & & $<0.05$ \\
\hline Female & $32.9 \pm 23.4$ & $32.7 \pm 23$ & & $35.9 \pm 23$ & & $<0.05$ \\
\hline \multicolumn{7}{|l|}{$0-6$ years } \\
\hline Male & 24,979 & 24,735 & $-1.0 \%$ & 25,374 & $2.6 \%$ & $<0.05$ \\
\hline Female & 20,121 & 20,530 & $2.0 \%$ & 20,302 & $-1.1 \%$ & $<0.05$ \\
\hline \multicolumn{7}{|l|}{$7-18$ years } \\
\hline Male & 6845 & 7746 & $13.2 \%$ & 6145 & $-20.7 \%$ & $<0.05$ \\
\hline Female & 7002 & 7599 & $8.5 \%$ & 7914 & $4.1 \%$ & $<0.05$ \\
\hline \multicolumn{7}{|l|}{$19-65$ years } \\
\hline Male & 22,182 & 23,422 & $5.6 \%$ & 24,923 & $6.4 \%$ & $<0.05$ \\
\hline Female & 50,353 & 51,633 & $2.6 \%$ & 41,570 & $-19.5 \%$ & $<0.05$ \\
\hline \multicolumn{7}{|l|}{$65+$ years } \\
\hline Male & 3949 & 3544 & $-0.1 \%$ & 3979 & $12.3 \%$ & $<0.05$ \\
\hline Female & 9533 & 9339 & $-2.1 \%$ & 12,957 & $38.7 \%$ & $<0.05$ \\
\hline \multicolumn{7}{|l|}{$\begin{array}{l}\text { Patient died at } \\
\text { scene }\end{array}$} \\
\hline $\begin{array}{l}\text { Died at } \\
\text { scene }\end{array}$ & $21(0.01 \%)$ & $13(0.01 \%)$ & $-0.4 \%$ & $10(0.01 \%)$ & $-0.2 \%$ & $<0.05$ \\
\hline $\begin{array}{l}\text { Sudden } \\
\text { death with } \\
\text { unknown } \\
\text { cause }\end{array}$ & $4(19 \%)$ & $2(15 \%)$ & $-0.5 \%$ & $1(10 \%)$ & $-0.5 \%$ & $<0.05$ \\
\hline $\begin{array}{l}\text { Cardiac } \\
\text { death }\end{array}$ & $12(57 \%)$ & $6(46 \%)$ & $-0.5 \%$ & $6(60 \%)$ & $0.0 \%$ & $<0.05$ \\
\hline Others & $5(24 \%)$ & $5(38 \%)$ & $0.0 \%$ & $3(30 \%)$ & $-0.4 \%$ & $<0.05$ \\
\hline
\end{tabular}

decrease in the number of patients, as well as a decline in the total number of patients in the age group of $19-65$ years by $11.4 \%$, while in the same group, the number of male patients increased during the pandemic period by $6.4 \%$. The number of patients in the 65+ age group enhanced by $31.5 \%$ during the pandemic period. There was a statistically significant difference between the age groups $(p<0.05)$

Industrial accidents $(-87 \%)$, road accidents $(-82 \%)$, and other accidents $(-78 \%)$ decreased during the pandemic period compared to the pre-pandemic period. The fact that all production facilities have been shut down, also with reduced machine traffic, moreover training activities, and flexible working hours in the public and private sectors, and quarantine restrictions may have been effective in this reduction. While suicides $(61 \%)$ and injuries (3\%) were elevated during the pandemic period (February 1-May 1, 2020). The number of medical cases increased by $21 \%$ over the same period (Table 3 ).

During the pandemic, the incidence of hypertension by $31 \%$, acute abdominal pain by $40 \%$, cerebrovascular diseases by $11 \%$, and alternative heart conditions by $29 \%$ minimized compared to the prepandemic amount (February 1-May 1, 2019), whereas the incidence of angina elevated by $32 \%$.

During the identical period, the signs and symptoms of fever considerably increased by $83 \%$. One of the maximum not unusual place signs and symptoms of COVID-19 is fever $[5,6]$. Therefore,
Table 3: Call causes and selected diagnoses

\begin{tabular}{|c|c|c|c|c|c|}
\hline Item & $\begin{array}{l}2018(n= \\
144,964)\end{array}$ & $\begin{array}{l}2019(n= \\
148,548)\end{array}$ & $\begin{array}{l}\text { Annual } \\
\text { difference \% }\end{array}$ & $\begin{array}{l}2020(n= \\
143,164)\end{array}$ & $\begin{array}{l}\text { Annual } \\
\text { difference \% }\end{array}$ \\
\hline \multicolumn{6}{|l|}{ Cause of call } \\
\hline Medical causes & $\begin{array}{l}71,212 \\
(49.1 \%)\end{array}$ & $\begin{array}{l}65,313 \\
(44 \%)\end{array}$ & $-8.3 \%$ & $\begin{array}{l}79,235 \\
(55 \%)\end{array}$ & $21 \%$ \\
\hline Work accidents & $117(0.1 \%)$ & $105(0.1 \%)$ & $-10 \%$ & $14(0.01 \%)$ & $-87 \%$ \\
\hline Suicides & $220(0.2 \%)$ & $31(0.02 \%)$ & $-86 \%$ & $50(0.03 \%)$ & $61 \%$ \\
\hline Injuries & $\begin{array}{l}9316 \\
(6.4 \%)\end{array}$ & $\begin{array}{l}10,906 \\
(7.3 \%)\end{array}$ & $17 \%$ & $\begin{array}{l}11,237 \\
(8 \%)\end{array}$ & $3 \%$ \\
\hline Other accidents & $\begin{array}{l}3552 \\
(2.5 \%)\end{array}$ & $\begin{array}{l}4629 \\
(3.1 \%)\end{array}$ & $30 \%$ & $1008(1 \%)$ & $-78 \%$ \\
\hline \multicolumn{6}{|l|}{$\begin{array}{l}\text { Time-sensitive } \\
\text { diseases }\end{array}$} \\
\hline $\begin{array}{l}\text { Other heart } \\
\text { diseases }\end{array}$ & $\begin{array}{l}2028 \\
(1.4 \%)\end{array}$ & $\begin{array}{l}2213 \\
(1.5 \%)\end{array}$ & $9.1 \%$ & $1563(1 \%)$ & $-29 \%$ \\
\hline Hypertension & $\begin{array}{l}12,815 \\
(8.8 \%)\end{array}$ & $\begin{array}{l}12,852 \\
(8.7 \%)\end{array}$ & $0.3 \%$ & $8848(6 \%)$ & $-31 \%$ \\
\hline Angina pectoris & $34(0.02 \%)$ & $22(0.01 \%)$ & $-35 \%$ & $29(0.02 \%)$ & $32 \%$ \\
\hline Acute abdomen & $\begin{array}{l}25,311 \\
(17.5 \%)\end{array}$ & $\begin{array}{l}22,708 \\
(15.3 \%)\end{array}$ & $-10 \%$ & $\begin{array}{l}13,587 \\
(9 \%)\end{array}$ & $-40 \%$ \\
\hline $\begin{array}{l}\text { Cerebrovascular } \\
\text { disease }\end{array}$ & $286(0.2 \%)$ & $280(0.2 \%)$ & $-2.1 \%$ & $250(0.2 \%)$ & $-11 \%$ \\
\hline \multicolumn{6}{|l|}{$\begin{array}{l}\text { COVID-19-related } \\
\text { symptoms }\end{array}$} \\
\hline Fever & - & $6(0.004 \%)$ & $0 \%$ & $11(0.01 \%)$ & $83 \%$ \\
\hline High temperature & $\begin{array}{l}19,590 \\
(13.5 \%)\end{array}$ & $\begin{array}{l}29,034 \\
(19.5 \%)\end{array}$ & $48 \%$ & $\begin{array}{l}25,482 \\
(18 \%)\end{array}$ & $-12 \%$ \\
\hline $\begin{array}{l}\text { Patients suspected } \\
\text { of COVID-19 }\end{array}$ & - & - & - & $279(0.2 \%)$ & \\
\hline $\begin{array}{l}\text { Patients diagnosed } \\
\text { with COVID-19 }\end{array}$ & - & - & - & $1491(1 \%)$ & \\
\hline
\end{tabular}

we consider that the growth in those signs and symptoms is as a result of COVID-19. Of all of the instances taken to the hospital, $0.2 \%$ have been suspected of COVID-19 and $1 \%$ have been identified with COVID-19 (Table 3).

\section{Discussion}

The study aimed to analyze the dynamics of changes in the number of emergency medical calls during the COVID-19 pandemic. Regarding the day of the week, it was found that cases of EMS were most frequent on Sundays and Mondays throughout the pre-pandemic period, whereas during the 2020 pandemic, it occurred on Mondays and Thursdays and there was a tendency to reduce the number of calls from the beginning of the day of the week to the weekend. The explanation for the decrease within the number of calls during the pandemic on Saturdays and Sundays could also be as a result of quarantine restrictions on weekends. The ambulance time of arrival not have accrued too much, because the range of employees was increased by taking action within the call center, and therefore, the EMS staff worked faithfully. Moreover, this was expedited by reduced operating hours and reduced traffic density as a results of the introduction of quarantine measures and lockdown [7].

In terms of gender, the number of male 
patients increased during the pandemic period, compared to the pre-pandemic period, and showed a difference of $14.05 \%$ increase, which is related to some of international studies discovering that COVID19 is deadlier for infected men than women with $2.8 \%$ fatality rate being reported in Chinese men versus $1.7 \%$ in women. Further, sex-disaggregated data for COVID-19 in several European countries show a similar number of cases between the sexes, but more severe outcomes in aged men [8]. Moreover, during the pandemic period, the average age of men and women increased.

Furthermore, concerning of age, the number of patients in the $65+$ age group enhanced by $31.5 \%$ during the pandemic period, we believe that this is often principally because of suspected or diagnosed cases of COVID-19 additionally the prevalence of COVID-19 within the elderly. In studies, the common age of patients with COVID-19 was 59 years [9]. The rise in the number of cases in these age groups also explains the increase in the average age of each men and women. The quantity of patients who died at the scene in the pre-pandemic amount (February 1-May 1, 2018) was $21(0.01 \%)$ and (February 1 -May 1,2019$)$ was also $0.01 \%$, in the pandemic period, this indicator remained unchanged $(0.01 \%)$. The foremost common reason for death at the scene, both in the pre-pandemic period and in the pandemic period, was "cardiac death." Coronary cardiopathy and stroke are the most important killers worldwide, leading to 15.2 million deaths in 2016. These diseases are the leading causes of death worldwide for the past 15 years [10]. Conjointly in Kazakhstan, the foremost common causes of death are coronary heart disease [11]. Furthermore, thrombosis ensuing from COVID-19 will result in unforeseen cardiac death [12].

In the matter of causes for the calls, we have a tendency to found that the frequency of emergency medical visits, notably for heart disease (hypertension), surgical emergencies (acute abdomen), and neurological emergencies

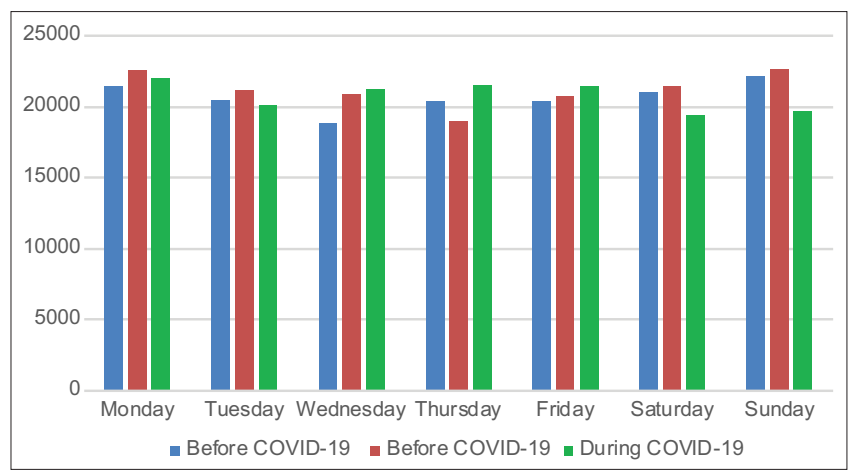

Figure 1: Comparison of the number of EMS calls per day of the week earlier than and during COVID-19. Before COVID-19 pandemic was identified as February 1-May 1, 2018-2019. "During COVID-19" was identified as February 1-May 1, 2020 (cerebrovascular diseases), decreased throughout the pandemic. In Nur-Sultan, special measures were taken to supply emergency cardiological, surgical, and neurological care. In some hospitals, wards were reserved for patients during this cluster while not contact with COVID-19. Despite these measures, the decline within the number of patients during this group is also thanks to the actual fact that patients deferred their medical wants and failed to wish to travel to the hospital for concern of transmitting COVID-19.

\section{Conclusions}

During the COVID-19 pandemic, EMS call rates had been maximum common on Mondays and Thursdays $(+13,75 \%)$. The evaluation suggests that the quantity of male sufferers extended by $14,05 \%$ in the course of the pandemic length, as compared to the pre-pandemic length. The quantity of patients with inside the $65+$ age group in the course of the pandemic length has extended by $31.5 \%$. During the pandemic, the signs and symptoms of fever enlarged significantly by $83 \%$. During the COVID $\square 19$ pandemic, using EMS particularly for time touchy illnesses, which include hypertension $(-31 \%)$, surgical emergencies (acute abdomen) $(-40 \%)$, cerebrovascular illnesses $(-11 \%)$, and other heart illnesses (-29\%) decreased.

\section{References}

1. World Health Organization. 2019-nCoV. Available from: https:// www.who.int/emergencies/diseases/novel-coronavirus-2019. [Last accessed 2020 Apr 25].

2. World Health Organization. News on Disease Outbreaks. Available from: https://www.who.int/csr/don/en. [Last accessed on 2020 Apr 25].

3. World Health Organization. Reports on the Current Situation. Available form: https://www.who.int/emergencies/diseases/ novel-coronavirus-2019/situation-reports. [Last accessed on 2020 Apr 25].

4. Roudsari BS, Nathens AB, Arreola-Risa C, Cameron P, Civil I, Grigoriou G, et al. Emergency medical service (EMS) systems in developed and developing countries. Injury. 2007;38(9):1001-13. PMid:17583709

5. Huang C, Wang Y, Li X, Ren L, Zhao J, Hu Y, et al. Clinical features of patients infected with 2019 novel coronavirus in Wuhan, China. Lancet. 2020;395:497-506. https://doi. org/10.1016/S0140-6736(20)30183-5

6. Tu H, Tu S, Gao S, Shao A, Sheng J. Current epidemiological and clinical features of COVID-19; a global perspective from China. J Infect. 2020;81(1):1-9. https://doi.org/10.1016/j.jinf.2020.04.011 PMid:32315723

7. Resolution of the Chief State Sanitary Doctor of December 25, 2020 No. 68 On Restrictive Quarantine Measures and Their 
Gradual Mitigation. Available from: https://www.online.zakon.kz/ Document/?doc_id=35809683. [Last accessed on 2021 May 15].

8. Gebhard C, Regitz-Zagrosek V, Neuhauser HK, Morgan R, Klein SL. Impact of sex and gender on COVID-19 outcomes in Europe. Biol Sex Differ. 2020;11(1):29. https://doi.org/10.1186/ s13293-020-00304-9

PMid:32450906

9. Wang D, Hu B, Hu C, Zhu F, Liu X, Zhang J, et al. Clinical characteristics of 138 hospitalized patients with 2019 novel coronavirus-infected pneumonia in Wuhan, China. JAMA. 2020;323(11):1061-9. https://doi.org/10.1001/jama.2020.1585

PMid:32031570
10. World Health Organization. The Top 10 Causes of Death Available from: http://www.who.int/mediacentre/factsheets/ fs310/en. [Last accessed on 2020 Apr 25].

11. Ministry of Health of the Republic of Kazakhstan. Health of the Population of the Republic of Kazakhstan and the Activities of Health Organizations. Statistical Collection. Kazakhstan: Ministry of Health of the Republic of Kazakhstan; 2019.

12. Guo T, Fan Y, Chen M, Wu X, Zhang L, He T, et al. Cardiovascular implications of fatal outcomes of patients with coronavirus disease 2019 (COVID-19). JAMA Cardiol. 2020;5(7):811-8. https://doi.org/10.1001/jamacardio.2020.1017 PMid:32219356 